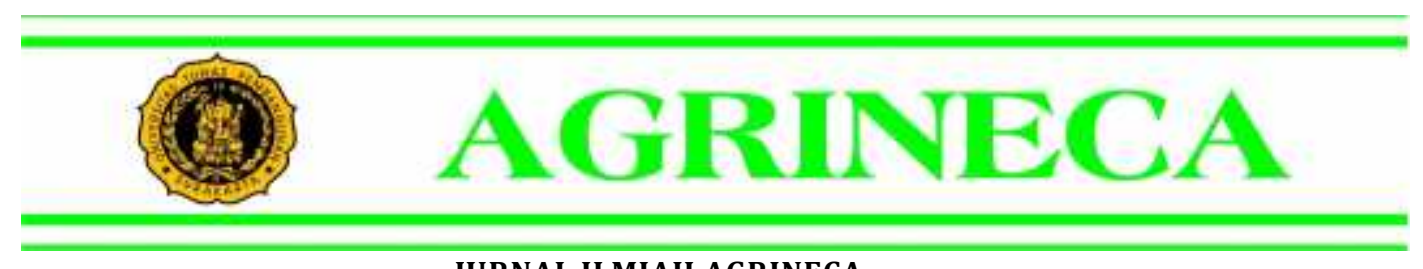

JURNAL ILMIAH AGRINECA

ISSN : 2721-074X (Online) - 2301-6698 (Print)

Available on : http://ejournal.utp.ac.id/index.php/AFP/index

This is Under CC BY SA Licence

\title{
PENGARUH KONSENTRASI DAN LAMA PERENDAMAN STEK LADA (Piper nigrum) DALAM LARUTAN ZAT PENGATUR TUMBUH (AUKSIN)
}

\section{The Effect Of Concentration and Time Immersion of Pepper Cuttings (Piper Nigrum) In A Growth Regulator (Auxine)}

\author{
Teguh Supriyadi, Tyas Soemarah K.D. " , Endang Suprapti, Agus Budiyono \\ Program Studi Agroteknologi, Fakultas Pertanian, Universitas Tunas Pembangunan \\ Jl. Balekambang Lor No. 1 Manahan, Surakarta \\ *Corresponden author: tskdmp@gmail.com
}

\begin{abstract}
Abstrak
Penelitian yang berjudul "Pengaruh Konsentrasi Dan Lama Perendaman Stek Lada (Piper nigrum) Dalam Larutan Zat Pengatur tumbuh (auksin)" ini dilaksanakan pada April - Juli 2020 di Green House Fakultas Pertanian Universitas Tunas Pembangunan, Jl. Balekambang Lor No. 1 Manahan, Surakarta. Penelitian ini menggunakan metode percobaan faktorial dengan dasar Rancangan Acak Lengkap (RAL) yang terdiri atas 2 faktor sebagai perlakuan dan 3 ulangan. Faktor yang pertama, konsentrasi zat pengatur tumbuh (auksin) (K), terbagi atas 3 taraf, yakni: 100 ppm (K1), 200 ppm (K2) serta 300 ppm (K3); sedangkan faktor yang kedua, lama perendaman (P), juga terdiri atas 4 taraf, yakni: 2jam (P1), 2,5 jam (P2), 3 jam (P3) dan 3,5 jam (P4). Parameter yang diamati dalam penelitian ini berjumlah 9, dengan rincian sebagai berikut: Jumlah Tunas , Jumlah Daun, Panjang Tunas, bobot segar dan kering tunas, jumlah dan Panjang Akar, bobot segar serta Bobot Kering Akar. Berdasarkan dari hasil penelitian stek tanaman lada akibat perlakuan konsentrasi zat pengatur tumbuh (auksin) dan lama perendaman menunjukkan hasil bahwa : Perlakuan lama perendaman berpengaruh nyata pada parameter pengamatan, yaitu panjang tanaman pada perlakuan $\mathrm{P}_{2}$ (2,5 jam). Dan tidak berpengaruh pada parameter Jumlah Tunas, Jumlah Daun, bobot segar dan kering tunas, jumlah dan Panjang Akar, bobot segar serta Bobot Kering Akar.

Kata Kunci : Tanaman Lada (Piper Nigrum L.), Konsentrasi, lama perendaman, stek, rootone F, IBA, IAA, NAA, dan Hormon Auksin
\end{abstract}

\section{ABSTRACT}

The research entitled "The Effect of Concentration and Soaking Time of Pepper Cutters (Piper nigrum) in a Solution of Growth Regulatory Substances (auxin)" was carried out. Research was held on April - July 2020 in Green House of 
This is Under CC BY SA Licence

Agriculture Faculty, Tunas Pembangunan University, Jl. Balekambang Lor No. 1 Manahan, Surakarta. This study used a factorial experimental method based on a completely randomized design (CRD) consisting of 2 factors as treatment and 3 replications. The first factor, the concentration of growth regulators (auxin) (K), is divided into 3 levels, namely: 100 ppm (K1), 200 ppm (K2) and 300 ppm (K3); while the second factor, immersion time $(P)$, also consists of 4 levels, namely: 2 hours $(P 1)$, 2.5 hours $(P 2), 3$ hours $(P 3)$ and 3.5 hours $(P 4)$. The parameters observed in this study amounted to 9, with details as follows: Number of shoots, number of leaves, length of shoots, fresh and dry weight of shoots, number and length of roots, fresh weight and root dry weight. Based on the results of research on pepper cuttings due to the concentration of growth regulators (auxin) and the duration of immersion, the results showed that: Soaking time had a significant effect on the observed parameters, namely plant length in P2 treatment (2.5 hours). And it did not affect the parameters of the number of shoots, number of leaves, fresh and dry weight of shoots, number and length of roots, fresh weight and root dry weight.

Keywords: Pepper (Piper Nigrum L.), concentration, soaking time, cuttings, rootone F, IBA, IAA, NAA, and auxin hormone.

\section{PENDAHULUAN}

Lada (Piper Nigrum L) dikenal sebagai tanaman rempah-rempah yang dapat menghangatkan tubuh. Selain itu, tanaman lada dapat digunakan sebagai bumbu masak. Tanaman lada juga dikenal sebagai tanaman tahunan yang memanjat, namun saat ini telah dihasilkan jenis lada perdu yang tumbuh tidak harus mengunakan tiang panjat, meski panjangnya bisa mencapai lebih dari $5 \mathrm{~cm}$, lada merupakan komoditas ekspor tertua bagi indonesia.

Salah satu faktor yang menghambat penyebab rendahnya produksi lada adalah dalam pengadaan bibit petani tidak melakukan dengan semestinya. seharusnya petani melakukan pengadaan bibit untuk penanaman lada dilakukan secara perbanyakan vegetativ(stek).
Salah satu usaha untuk meningkatkan produksi adalah pengadaan bibit dengan cara perbanyakan vegetatif secara stek yang kegiatannya meliputi : memilih cabang stek, memotong cabang stek, memberi perlakukan, menyiapkan media stek, menanam stek, dan memasang sungkup. Dengan pengadaan bibit yang baik dan disertai adanya perlakuan yang maksimal akan diperoleh produksi yang memuaskan .

Dengan sistem tersebut diharapkan mampu menghasilkan lada berkualitas tinggi (bebas dari senyawa/polutan an organik racun), melalui penggunaan varietas unggul, sehat, tahan hama penyakit, memaksimalkan penggunaan pupuk organik, menggunakan pestisida nabati dan penggunaan agensia hayati, (Sulkani, 2013). 


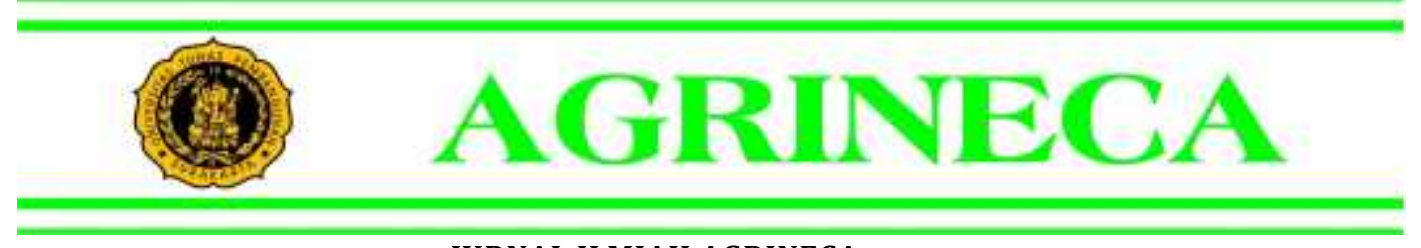

JURNAL ILMIAH AGRINECA

ISSN : 2721-074X (Online) - 2301-6698 (Print)

Available on : http://ejournal.utp.ac.id/index.php/AFP/index

This is Under CC BY SA Licence

Zat pengatur tumbuh akar yang banyak dipergunakan akhir-akhir ini, dijumpai dalam bentuk tepung putih dan berguna untuk mempercepat dan memperbanyak keluarnya akar-akar baru, karena mengandung bahan aktif dari hasil formulasi beberapa hormon tumbuh akar yaitu IBA, IAA, dan NAA (Anonim, 1987). Penggunaan Zat pengatur tumbuh (auksin) sebagai hasil kombinasi dari ketiga jenis hormon tumbuh di atas lebih efektif merangsang perakaran dari pada penggunaan hanya satu jenis hormon secara tunggal pada konsentrasi sama.

Zat pengatur tumbuh (auksin) merupakan ZPT sintetik yang bahan aktifnya merupakan gabungan dari IBA dan NAA yang sangat efektif merangsang pertunasan dan pertumbuhan perakaran stek (Kosasih \& Rochayat 2000, Arinasa et al. 2015). Pertumbuhan stek dipengaruhi oleh ukuran stek. Panjang stek menentukan jumlah cadangan makanan yang terkandung dalam setek. Panjang stek juga menunjukkan 2 persediaan energi yang diperlukan dalam pertumbuhan akar dan tunas lebih banyak. Penggunaan panjang stek pucuk dengan ukuran 5-10 $\mathrm{cm}$ (3-5 ruas) lebih efisien dalam penggunaan bahan material stek karena secara morfologi perawakan tanaman B. tuberosa Lmk. tingginya tidak lebih dari $30 \mathrm{~cm}$. Hasil penelitian bambu petung hitam menggunakan Rootone-F menunjukkan bahwa penggunaan konsentrasi $400 \mathrm{mg} / \mathrm{l}$ memberikan hasil yang paling optimal untuk pertumbuhan Panjang Akar dan
Jumlah Daun (Arinasa et al. 2015). Hal senada juga ditunjukkan oleh stek batang tanaman anggur yang terdiri atas tiga sampai empat mata tunas dengan panjang 25-30 cm memberikan hasil yang lebih baik.

Berdasarkan dari hasil penelitian Huik (2004), menunjukan bahwa zat pengatur tumbuh Zat pengatur tumbuh auksin (Rootone-F) berpengaruh nyata terhadap persen tumbuh tunas, Jumlah Akar, berat kering akar, berat kering tunas, dan mengindikasikan bahwa pemberian Rootone-F dapat menunjukkan pertumbuhan dan perkembangan stek batang Tectona grandis L (Ali, 2016). Pemberian dosis Rootone-F pada stek Rosamala (A.excelsa) dengan dosis $50 \mathrm{mg}$ menghasilkan prsentase hidup (91.67\%) dan persentase berakar $(67.50 \%)$ yang terbaik (Rifai H, 2010). Selain itu, pemberian Rootone-F dengan dosis $100 \mathrm{mg} / \mathrm{stek}$ berpengaruh nyata terhadap pertumbuhan Jumlah Akar, Panjang Akar, Bobot Segar Akar, dan Bobot Kering Akar stek buah naga (Yunianto, 2014)

Lama perendaman sangat penting bagi proses penyerapan Rootone-F pada stek batang. Menurut manope (2013), mengatakan bahwa lama perendaman dalam larutan zat pengatur tumbuh juga berpengaruh terhadap tingkat kaberhasilan pertumbuhan stek. Budianto et al. (2013), menyatakan bahwa perlakuan lama perendaman dengan IBA selama 3 jam memberikan pengaruh secara nyata terhadap parameter Panjang 


\section{AGRINECA}

JURNAL ILMIAH AGRINECA

ISSN : 2721-074X (Online) - 2301-6698 (Print)

Available on : http://ejournal.utp.ac.id/index.php/AFP/index

This is Under CC BY SA Licence

Akar, Jumlah Daun, dan Bobot Kering Akar pada stek tanaman sirih merah

Penelitian tentang konsentrasi

dan lama perendaman Rootone-F

dipaparkan oleh beberapa peneliti pada perbanyakan tanaman dengan metode stek. Seperti yang disampaikan Wiratri (2005), bahwa stek pucuk tanaman gmelina yang direndam dalam larutan Rootone-F 100 ppm selama 24 jam merupakan cara yang paling baik. Sudrajat, dan Harto (2011), mengatakan bahwa perendaman dengan Rootone-F 300 mg/1 direndam selama 3 jam memberikan hasil terbaik pada rata-rata Panjang Tunas $(5,67$ $\mathrm{cm})$, Jumlah Daun $(7,67 \mathrm{~cm})$, dan Jumlah Akar pada tanaman pule pandak, dibandingkan dengan perlakuan IBA dengan konsentrasi 150 dengan lama perendaman 24 jam mendapatkan hasil paling tinggi pada rata-rata Jumlah Akar 3,33 pada tanaman jeruk (Kusdianto, 2012)

Penelitian Arsyadmunir (2013) bahwa pada tanaman sirih merah dengan perlakuan kombinasi macam ZPT dan lama perendaman memberikan pengaruh pada parameter saat muncul tunas, Jumlah Daun, Panjang Tunas, Jumlah Akar, Panjang Akar, Bobot Kering Akar dan bobot kering daun. Pada parameter saat muncul tunas paling baik pada perlakuan NAA yang direndam selama 1 jam yaitu sebesar 8,92 HST, dibandingkan dengan kontrol 10,5 HST. Jumlah daun paling banyak pada perlakuan NAA yang direndam selama 1 jam menunjukkan hasil sebesar 6,33 helai, dibandingkan kontrol yaitu 4,08 helai. Panjang tunas paling baik pada perlakuan NAA selama 1 jam sebesar $27,98 \mathrm{~cm}$ pada umur 12 MST dibandingkan kontrol sekitar 10,91 cm dan terus mengalami penigkatan mulai umur 6 MST. Pada Jumlah Akar terbaik pada perlakuan IBA selama 3 jam sebesar 20,50 helai saat umur 12 MSTdan pada perlakuan NAA selama 1 jam juga meningkat menjadi 14,25 helai dibandingkan pada kontrol yaitu 10,50 helai. Panjang akar paling baik pada perlakuan IBA selama 3 jam sebesar 20,42 cm dibandingkan ddengan kontrol 11,54 cm. Pada Bobot Kering Akar terbaik pada perlakuan IBA selama 3 jam sebesar 0,57 $\mathrm{g}$ dibandingkan dengan kontrol sekitar 0,16 g. Dan pada parameter bobot kering daun paling baik pada perlakuan NAA selama 1 jam sebesar $1,42 \mathrm{~g}$ dibanding dengan kontrol yaitu $0,59 \mathrm{~g}$.

\section{Rumusan Masalah}

1. Apakah konsentrasi Zat pengatur tumbuh (auksin) berpengaruh terhadap pertumbuhan bibit stek tanaman Lada (Piper nigrumLinnaeus)?

2. Apakah lama perendaman Zat pengatur tumbuh (auksin) berpengaruh terhadap pertumbuhan bibit stek tanaman Lada (Piper nigrumLinnaeus)?

3. Adakah interaksi antara konsentrasi dan lama perendaman Zat pengatur tumbuh (auksin)berpengaruh terhadap pertumbuhan bibit stek tanaman Lada (Piper nigrumLinnaeus)? 


\section{AGRINECA}

JURNAL ILMIAH AGRINECA

ISSN : 2721-074X (Online) - 2301-6698 (Print)

Available on : http://ejournal.utp.ac.id/index.php/AFP/index

This is Under CC BY SA Licence

\section{Tujuan Penelitian}

1. Untuk mengetahui pengaruh konsentrasi Zat pengatur tumbuh (auksin) terhadap pertumbuhan stek tanaman Lada (Piper nigrum Linnaeus).

2. Untuk mengetahui pengaruh lama perendaman dalam Zat pengatur tumbuh (auksin) terhadap pertumbuhan stek tanaman Lada (Piper nigrumLinnaeus).

3. Untuk mengetahui interaksi antara konsentrasi dan lama perendaman Zat pengatur tumbuh (auksin) terhadap pertumbuhan bibit stek tanaman Lada (Piper nigrumLinnaeus).

\section{Hipotesis}

Diduga pertumbuhan terbaik padakombinasi P1K2 yaitu konsentrasi 200 dengan lama perendaman 2,5 jam

\section{METODE PENELITIAN}

\section{Waktu dan Tempat}

Penelitian dilaksanakan bulan April - Juli 2020 di Green House Fak.Pertanian UTP

\section{Alat dan Bahan}

1. Alat

Alat yang digunakan adalah pisau, gunting, kantong plastik, plastik transparan, gelas ukur, gelas plastik, cangkul, penggaris, timbangan, kertas label, sprayer, ember dan alat tulis.

2. Bahan
Bahan yang digunakan adalah batang tanaman Lada 2 ruas, ZPT (auksin), aquades, air, fungisida dan media tanam dari tanah, pasir dan kompos.

\section{Metode Penelitian}

Penelitian ini menggunakan percobaan faktorial dengan rancangan dasar Rancangan Acak Lengkap ( RAL ). Ada 2 (dua) faktor perlakuan yaitu konsentrasi Rootone-F (K) dengan 3 taraf dan lama perendaman (P) dengan 4 taraf. Dengan perincian sebagai berikut :

1. Faktor I : Konsentrasi Rootone-F (K) yang terdiri dari 3 taraf, yaitu : -K1:Konst $100 \mathrm{mg} / 1 \mathrm{~L}=0.01 \%$ -K2:Konst $200 \mathrm{mg} / 1 \mathrm{~L}=0.02 \%$ -K3:Konst300 mg/ $1 \mathrm{~L}=0.03 \%$

2. Faktor II : Lama perendaman (P) terdiri dari 4 taraf, yaitu :

-P1 : 2 jam

-P2 : 2,5 jam

-P3 : 3 jam

-P4 : 3,5 jam

Dari kedua faktor tersebut diatas maka diperoleh 12 kombinasi perlakuan, setiap kombinasi diulang sebanyak 3 kali, sehingga terdapat 36 satuan percobaan dan setiap satuan percobaan terdiri dari 3 tanaman stek lada, jadi keseluruhan terdapat 108 polibag.

\section{Parameter Pengamatan}

$$
\text { Pengamatan dilaksakanan } 1
$$
minggu sekali setelah tanaman berumur 2 MST. Pengamatan dilakukan parameter sebagai berikut : 
This is Under CC BY SA Licence

1. Jumlah Tunas (batang)

2. Panjang Tanaman $(\mathrm{cm})$

3. Jumlah Daun (helai)

4. Jumlah Akar (helai)

5. Panjang Akar $(\mathrm{cm})$

6. Bobot Segar Tanaman (g)

7. Bobot Kering Tunas (g)

8. Bobot Segar Akar (g)

9. Bobot Kering Akar (g)

\section{HASIL DAN PEMBAHASAN}

\section{Hasil Pengamatan Perlakuan Konsentrasi dan Lama Perendaman ZPT Auksin}

Untuk mengetahui pengaruh taraf perlakuan pemberian konsentrasi Zat Pengatur Tumbuh dan lama perendaman dilakukan Uji DMRT (Duncan Multiple Range Test) 5\% yaitu Uji yang dilakukan karena adanya perbedaan nyata pada hasil analisis varians yang hasilnya disajikan pada tabel dibawah ini :

Tabel 1 Uji Jarak Berganda Duncan's $5 \%$, Pengaruh pemberian konsentrasi Zat Pengatur Tumbuh dan lama perendaman

\begin{tabular}{|c|c|c|c|c|c|c|c|c|c|}
\hline \multirow[b]{2}{*}{ Perlakuan } & \multicolumn{9}{|c|}{ Parameter } \\
\hline & $\begin{array}{c}\text { Jumlah } \\
\text { Daun } \\
\text { (helai) }\end{array}$ & $\begin{array}{l}\text { Jumlah } \\
\text { Tunas } \\
\text { (batang) }\end{array}$ & $\begin{array}{c}\text { Panjang } \\
\text { Tanaman } \\
\text { (cm) }\end{array}$ & $\begin{array}{c}\text { Berat } \\
\text { Segar } \\
\text { Tanaman } \\
\text { (g) }\end{array}$ & $\begin{array}{c}\text { Berat } \\
\text { Kering } \\
\text { Tanaman } \\
\text { (g) }\end{array}$ & $\begin{array}{c}\text { Berat } \\
\text { Segar } \\
\text { Akar } \\
\text { (g) }\end{array}$ & $\begin{array}{c}\text { Berat } \\
\text { Kering } \\
\text { Akar (g) }\end{array}$ & $\begin{array}{c}\text { Jumlah } \\
\text { Akar }\end{array}$ & $\begin{array}{c}\text { Panjang } \\
\text { Akar } \\
\text { (cm) }\end{array}$ \\
\hline \multicolumn{10}{|c|}{ Perlakuan (K) } \\
\hline K1 & 8,25 & 1,42 & 34,76 & 7,83 & 3,53 & 2,99 & 1,82 & 14,14 & 7,75 \\
\hline $\mathrm{K} 2$ & 7,2 & 1,23 & 36,09 & 7,85 & 3,55 & 3,03 & 1,85 & 13,5 & 7,87 \\
\hline $\mathrm{K} 3$ & 6,45 & 1,31 & 31,03 & 7,73 & 3,5 & 3,07 & 1,85 & 13,59 & 7,92 \\
\hline \multicolumn{10}{|c|}{ Perlakuan $(\mathrm{P})$} \\
\hline P1 & 7,41 & 1,3 & $32,43 a$ & 7,7 & 3,46 & 2,95 & 1,79 & 13,89 & 7,56 \\
\hline $\mathrm{P} 2$ & 8,3 & 1,5 & $41,3 b$ & 7,82 & 3,52 & 3,07 & 1,89 & 14 & 7,85 \\
\hline P3 & 7,12 & 1,38 & $33,05 a$ & 8,09 & 3,67 & 2,95 & 1,78 & 13,26 & 8,12 \\
\hline$\overline{\mathrm{P} 4}$ & 6,37 & 1,12 & $29 a$ & 7,6 & 3,44 & 3,13 & 1,89 & 13,8 & 7,85 \\
\hline \multicolumn{10}{|c|}{ Kombinasi Perlakuan $(\mathrm{K} \times \mathrm{P})$} \\
\hline K1P1 & 8,56 & 1,34 & 31,856 & $7,05+2,79$ & 3,16 & 2,79 & 1,7 & 13,45 & 7,34 \\
\hline K1P2 & 11,12 & 1,78 & 49,344 & 7,5 & 3,38 & 2,93 & 1,76 & 13,89 & 7,89 \\
\hline K1P3 & 6,9 & 1,34 & 29,811 & 8,52 & 3,86 & 2,95 & 1,8 & 14,23 & 8 \\
\hline K1P4 & 6,45 & 1,23 & 28,022 & 8,27 & 3,73 & 3,3 & 1,99 & 15 & 7,78 \\
\hline K2P1 & 6,56 & 1 & 32,478 & 7,84 & 3,52 & 3,09 & 1,86 & 14,12 & 7,45 \\
\hline K2P2 & 7,67 & 1,45 & 43,789 & 7,95 & 3,57 & 3,09 & 1,97 & 13,78 & 7,89 \\
\hline K2P3 & 7,45 & 1,45 & 34,378 & 7,69 & 3,48 & 2,97 & 1,78 & 12,45 & 8,34 \\
\hline K2P4 & 7,12 & 1 & 33,689 & 7,93 & 3,63 & 2,96 & 1,79 & 13,67 & 7,78 \\
\hline K3P1 & 7,12 & 1,56 & 32,978 & 8,22 & 3,7 & 2,99 & 1,79 & 14,12 & 7,89 \\
\hline$\overline{\mathrm{K} 3 \mathrm{P} 2}$ & 6,12 & 1,23 & 30,867 & 7,99 & 3,63 & 3,22 & 1,95 & 14,45 & 7,78 \\
\hline K3P3 & 7 & 1,34 & 34,967 & 8,09 & 3,69 & 2,94 & 1,76 & 13,12 & 8 \\
\hline K3P4 & 5,56 & 1,12 & 25,3 & 6,62 & 2,98 & 3,15 & 1,88 & 12,67 & 8 \\
\hline
\end{tabular}

Keterangan :

Perlakuan yang diikuti dengan satu huruf yang sama menunjukkan berbeda tidak nyata pada taraf 5\% uji jarak berganda Duncan's. 


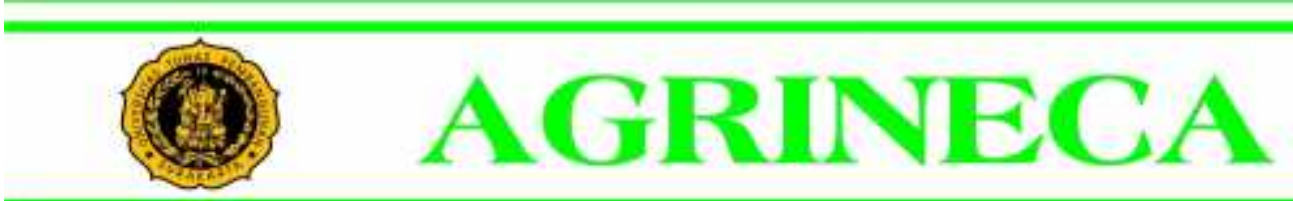

JURNAL ILMIAH AGRINECA

ISSN : 2721-074X (Online) - 2301-6698 (Print)

Available on : http://ejournal.utp.ac.id/index.php/AFP/index

This is Under CC BY SA Licence

Dalam Tabel 2 dapat dilihat perlakuan pemberian dosis Zat Pengatur Tumbuh Auksin ternyata tidak berpengaruh nyata terhadap semua parameter Jumlah daun, Jumlah tanaman, Panjang Tanaman, Berat Segar Tanaman, Berat Kering Tanaman, Berat Segar Akar, Berat Kering Akar, Jumlah Akar dan Panjang Akar. ternyata penambahan konsentrasi Zat Pengatur Tumbuh Auksin tidak mempengaruhi semua parameter, hal ini ditunjukkan bahwa tidak ada penambahan Jumlah daun, Jumlah tanaman, Panjang Tanaman, Berat Segar Tanaman, Berat Kering Tanaman, Berat Segar Akar, Berat Kering Akar, Jumlah Akar dan Panjang Akar.

Hal ini diduga pemberian berbagai konsentrasi Rootone- $F$ dan kandungan karbohidrat dan nitrogen dari bahan stek tersebut kurang lebih sama sehingga jumlah karbohidrat yang terdapat didalam bahan stek jambu air ( Syzygium samarangense Blurm) hanya cukup untuk mempertahankan hidupnya dan tidak mencukupi untuk menginisiasi terbentuknya akar maupun Tanaman baru( Supriyanto dan Prakasa, 2011), ditambahkan juga, bahwa hormone eksogen dari Rootone-F bisa bersifat menghambat pertumbuhan akar pada kadar rendah tertentu zat pengatur tumbuh akan mendorong pertumbuhan, sedangkan pada kadar yang lebih tinggi akan menghambat pertumbuhan, meracuni, bahkan mematikan tanaman.

Selain itu, juga terdapat dua faktor yang mepengaruhi berhasil atau tidak suatu perbanyakan tanaman secara stek. Menurut Khair et al. (2013) bahwa faktor luar yang mempengaruhi adalah keadaan lingkungan, media tanam, dan perlakuan pada stek. Sedangkan faktor dalam meliputi ketersediaan zat pengatur tumbuh auksin dan karbohidrat yang terdapat di dalam bahan stek. Penyebab lain bisa juga disebabkan oleh bahan tanam stek sendiri, yang kemungkinan disebabkan oleh digunakannya batang-batang yang masih muda dan bahkan terlalu tua. Pernyataan ini sesuai yang dipaparkan oleh Khair et al. (2013), batang yang terlalu muda proses penguapannya akan sangat cepat sehingga stek akan menjadi lemah dan mati. Dan batang yang terlalu tua kandungan karbohidrat maupun hormon alami hanya sedikit dan hanya akan memperlambat pertumbuhan tunas dan akar. Hal ini ditandai dengan peluruhan daun dan tunas yang mengering, kemudian batang mulai mengering dan mati.

Perlakuan lama perendaman berpengaruh nyata pada terhadap 


\section{JURNAL ILMIAH AGRINECA}

ISSN : 2721-074X (Online) - 2301-6698 (Print)

Available on : http://ejournal.utp.ac.id/index.php/AFP/index

This is Under CC BY SA Licence

mampu untuk bertahan dan menginisiasi sel - sel akar baru pada stk. Selain itu, batang yang digunakan sebagai bahan stek memiliki jaringan sel yang sudah tua sehingga kemampuan untuk menginisiasi akar menurun meskipun ditambah dengan bantuan hormon Auksin

Untuk mengetahui hasil pelakuan konsentrasi dan lama perendaman disajikan dalam rangkuman rangkuman hasil penelitian Tabel 2 dibawah ini.

Tabel 2 Rangkuman Hasil Penelitian

\begin{tabular}{|l|c|c|c|c|c|}
\hline \multirow{2}{*}{ Parameter } & \multicolumn{3}{|c|}{ Perlakuan } & \multicolumn{2}{c|}{ Nilai } \\
\cline { 2 - 6 } & K & P & K x B & Tertinggi & Terendah \\
\hline $\begin{array}{l}\text { Jumlah Daun } \\
\text { (helai) }\end{array}$ & $\mathrm{ns}$ & $\mathrm{ns}$ & $\mathrm{ns}$ & $\begin{array}{c}11,6 \\
(\mathrm{~K} 2 \mathrm{P} 2)\end{array}$ & $\begin{array}{c}5 \\
(\mathrm{~K} 2 \mathrm{P} 1)\end{array}$ \\
\hline $\begin{array}{l}\text { Jumlah Tanaman } \\
\text { (helai) }\end{array}$ & $\mathrm{ns}$ & $\mathrm{ns}$ & $\mathrm{ns}$ & $\begin{array}{c}1,66 \\
(\mathrm{~K} 3 \mathrm{P} 3)\end{array}$ & $\begin{array}{c}1 \\
(\mathrm{~K} 1 \mathrm{P} 1)\end{array}$ \\
\hline $\begin{array}{l}\text { Panjang } \\
\text { Tanaman } \\
\text { (cm) }\end{array}$ & $\mathrm{ns}$ & $* *$ & $\mathrm{~ns}$ & $\begin{array}{c}52,03 \\
(\mathrm{~K} 1 \mathrm{P} 2)\end{array}$ & $\begin{array}{c}20,93 \\
(\mathrm{~K} 1 \mathrm{P} 4)\end{array}$ \\
\hline $\begin{array}{l}\text { Berat Segar } \\
\text { Tanaman (g) }\end{array}$ & $\mathrm{ns}$ & $\mathrm{ns}$ & $\mathrm{ns}$ & $\begin{array}{c}9,3 \\
(\mathrm{~K} 1 \mathrm{P} 4)\end{array}$ & $\begin{array}{c}5,3 \\
(\mathrm{~K} 1 \mathrm{P} 1)\end{array}$ \\
\hline $\begin{array}{l}\text { Berat Kering } \\
\text { Tanaman (g) }\end{array}$ & $\mathrm{ns}$ & $\mathrm{ns}$ & $\mathrm{ns}$ & $\begin{array}{c}4,3 \\
(\mathrm{~K} 1 \mathrm{P} 4)\end{array}$ & $\begin{array}{c}2,3 \\
(\mathrm{~K} 1 \mathrm{P} 2)\end{array}$ \\
\hline $\begin{array}{l}\text { Berat Segar Akar } \\
\text { (g) }\end{array}$ & $\mathrm{ns}$ & $\mathrm{ns}$ & $\mathrm{ns}$ & $\begin{array}{c}3,56 \\
(\mathrm{~K} 3 \mathrm{P} 4)\end{array}$ & $\begin{array}{c}2,4 \\
(\mathrm{~K} 1 \mathrm{P} 1)\end{array}$ \\
\hline $\begin{array}{l}\text { Berat Kering } \\
\text { Akar (g) }\end{array}$ & $\mathrm{ns}$ & $\mathrm{ns}$ & $\mathrm{ns}$ & $\begin{array}{c}2,13 \\
(\mathrm{~K} 3 \mathrm{P} 4)\end{array}$ & $\begin{array}{c}1,43 \\
(\mathrm{~K} 1 \mathrm{P} 1)\end{array}$ \\
\hline $\begin{array}{l}\text { Jumlah Akar } \\
\text { (helai) }\end{array}$ & $\mathrm{ns}$ & $\mathrm{ns}$ & $\mathrm{ns}$ & $\begin{array}{c}16 \\
(\mathrm{~K} 3 \mathrm{P} 1)\end{array}$ & $\begin{array}{c}11,67 \\
(\mathrm{~K} 1 \mathrm{P} 3)\end{array}$ \\
\hline $\begin{array}{l}\text { Panjang Akar } \\
\text { (cm) }\end{array}$ & $\mathrm{ns}$ & $\mathrm{ns}$ & $\mathrm{ns}$ & $\begin{array}{c}9 \\
(\mathrm{~K} 3 \mathrm{P} 4)\end{array}$ & $\begin{array}{c}6,67 \\
(\mathrm{~K} 1 \mathrm{P} 1)\end{array}$ \\
\hline
\end{tabular}

Keterangan :
* : : Berbeda Nyata
** : Berbeda Sangat Nyata
ns : Tidak Berbeda Nyata

\section{KESIMPULAN DAN SARAN}

\section{Kesimpulan}

Dari hasil penelitian stek tanaman lada akibat perlakuan konsentrasi Zat Pengatur Tumbuh auksin dan Lama perendaman dapat disimpulkan sebagai berikut :

1. Perlakuan konsentrasi larutan Zat Pengatur Tumbuh auksin tidak berpengaruh nyata pada parameter Jumlah daun, Jumlah tanaman, Panjang Tanaman, Berat Segar 


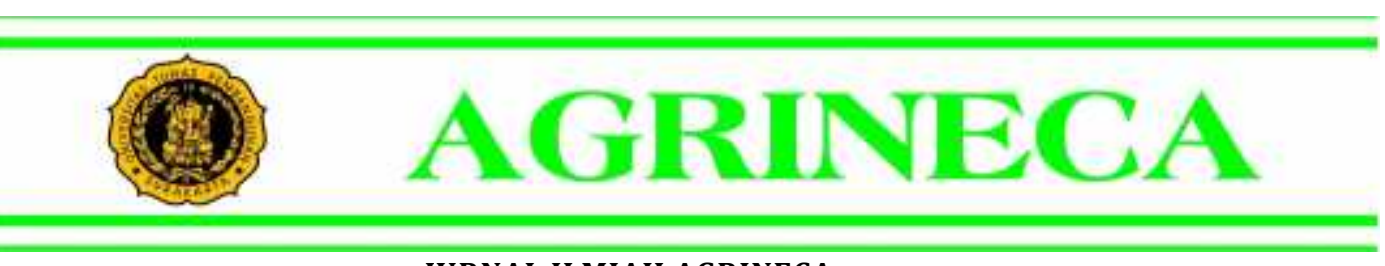

JURNAL ILMIAH AGRINECA

ISSN : 2721-074X (Online) - 2301-6698 (Print)

Available on : http://ejournal.utp.ac.id/index.php/AFP/index

This is Under CC BY SA Licence

Tanaman, Berat Kering Tanaman, Berat Segar Akar, Berat Kering Akar, Jumlah Akar dan Panjang Akar. .

2. Perlakuan lama perendaman dalam larutan Zat Pengatur Tumbuh auksin tidak berpengaruh nyata pada parameter Jumlah daun, Jumlah tanaman, Berat Segar Tanaman, Berat Kering Tanaman, Berat Segar Akar, Berat Kering Akar, Jumlah Akar dan Panjang Akar. Tetapi berpengaruh nyata pada panjang tanaman.

3. Interaksi konsentrasi hormon Auksin dan Lama perendaman tidak berpengaruh nyata pada parameter Jumlah daun, Jumlah tanaman, Panjang Tanaman, Berat Segar Tanaman, Berat Kering Tanaman, Berat Segar Akar, Berat Kering Akar, Jumlah Akar dan Panjang Akar.

4. Berat kering tanaman tertinggi pada perlakuan konsentrasi 0,01\% dengan lama perendaman 2,5 jam (K1P2) yaitu $52,03 \mathrm{~cm}$ dan terendah pada perlakuan konsentrasi $0,01 \%$ dengan lama perendaman 3,5 jam (K1P4) yaitu $20,93 \mathrm{~cm}$.

\section{Saran}

Pengunaan larutan Zat Pengatur Tumbuh hormon auksin pada konsentrasi 100 - 200 ppm sebaiknya disertai lama perendaman 2,5 - 3 jam untuk mendapatkan stek lada (Piper nigrum) dengan kualitas tunas terbaik.

\section{DAFTAR PUSTAKA}

Andriyanti A. 2008. Kajian Media Tanam Dan Konsentrasi BAP (Benzyl Amino Purin) Terhadap Pertumbuhan Setek Tanaman Buah Naga Daging Putih (Hylocereus Undatus). Tesis. Program Studi Agronomi Universitas Sebelas Maret Surakarta.

Anonim. 1987. Pedoman Penggunaan Hormon Tumbuh Akar Pada Pembibitan Beberapa Tanaman Kehutanan. Departemen Kehutanan Direktorat Jenderal Reboisasi dan Rehabilitasi Lahan.

Ali, M. (2016). Pembuatan PGPR (Plant Growth Promoting Rhizobacteria) Dari Akar Bambu. Development of Agriculture, 2(1), 1-12.

Arsyadmunir Ahmad. 2013. Pengaruh Kombinasi Macam Zpt Dengan Lama Perendaman YangBerbeda Terhadap Keberhasilan Pembibitan Sirih Merah(Piper Crocatum Ruiz \& Pav) Secara Stek. Agrovigor Vol. 6 No. 2. Fakultas Pertanian Universitas Trunojoyo Madura

Aurum M. 2005. Pengaruh Jenis Media Tanam Dan Pupuk Kandang Terhadap 


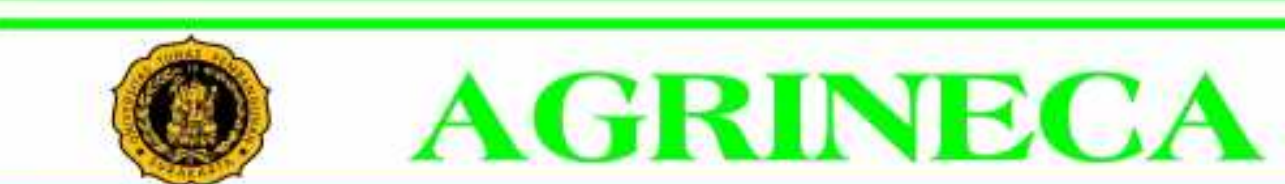

JURNAL ILMIAH AGRINECA

ISSN : 2721-074X (Online) - 2301-6698 (Print)

Available on : http://ejournal.utp.ac.id/index.php/AFP/index

This is Under CC BY SA Licence

Pertumbuhan Setek Sambang Colok (Aerva Sanguinolenta Blume.). Skripsi. Fakultas Pertanian Institut Pertanian Bogor.

Azomy Pane. M, M. M. B. Damanik, Bintang Sitorus. 2014.Pemberian Bahan Organik Kompos Jerami Padi dan Abu Sekam Padi dalam Memperbaiki Sifat Kimian Tanah Ultisol Serta Pertumbuhan Tanaman Jagung.Jurnal Online Agroekoteknologi . ISSN No. 2337- $6597 \quad$ Vol.2, No.4.Program Studi Agroekoteknologi, Fakultas Pertanian, USU.

Budianto E. A, Kaswan Badami, Ahmad Arsyadmunir. 2013. Pengaruh Kombinasi Macam Zpt Dengan Lama Perendaman Yang Berbeda Terhadap Keberhasilan Pembibitan Sirih Merah (Piper crucatum Ruiz \& Pav) SecaraStek. Jurnal Penelitian Agrovigor Volume 6 No. 2 ISSN 1979 5777. Fakultas Pertanian Universitas Trunojoyo Madura.

Budianto M. I, Ahmad Arsyadmunir, Suhartono. 2012. Pertumbuhan Stek cabe Jamu (Piper retrofractum. Vahl) Pada Berbagai Campuran Media Tanam Dan Konsentrsi Zat Pengatur Tumbuh RootoneF.Jurnalagrovigur volume 6 no
2. Fakultas pertanian universitas trunojoyo madura.

Febriana,S.2009. Pengaruh Konsentras iZPT Dan Panjang Stek Terhadap Pembentukan Alpokad (Persea Americana $M i l)$. Skripsi. Universitas IBA Palembang.

Hariadi N, Lilik Setyobudi, Ellis Nihayati. 2012. Studi Pertumbuhan Dan Hasil ProduksiJamur Tiram Putih (Pleorotus Ostreatus) Pada Media Tumbuh Jerami Padi Dan Serbuk Gergaji. Jurnal Produksi Tanaman Volume 1 No.1. Jurusan Budidaya Pertanian Fakultas Pertanian, Universitas Brawijaya.

Hayati E, Sabaruddin, Dan Rahmawati. 2007. Pengaruh Jumlah Mata Tunas Dan Komposisi Media Tanam Terhadap Pertumbuhan Setek Tanaman Jarak Pagar (Jatropha CurcasL.). JurnalAgrista Vol. 16 No. 3.Program Studi Agroteknologi Fakultas Pertanian Universitas Syiah Kuala, Banda Aceh.

http://repository.usu.ac.id/bitstream/12 3456789/19609/6/Chapter\%20II. pdf diunduh pada tanggal 28 Desember 2015.

https://id.wikipedia.org/wiki/Kompos. diunduh pada tanggal 28 Desember 2015. 


\section{AGRINECA}

JURNAL ILMIAH AGRINECA

ISSN : 2721-074X (Online) - 2301-6698 (Print)

Available on : http://ejournal.utp.ac.id/index.php/AFP/index

This is Under CC BY SA Licence

Huik E. M. 2004. Pengaruh Rootone - F Dan Ukuran Diameter Stek Terhadap Pertumbuhan Dari Stek Batang Jati (Tectona grandis L.). Skripsi. Jurusan Kehutanan Fakultas Pertanian Universitas Pattimura.

Islami, T. dan Utomo, W.H. 1995. Hubungan Tanah, Air dan Tanaman. IKIP Semarang Press, Semarang.

lampira Abidin, Z. 1990. Dasar-Dasar Pengetahuan Tentang Zat Pengatur Tumbuh. Penerbit Angkasa, Bandung.

Mayasari E, Lukas S. Budipramana, Yuni Sri Rahayu. 2012 Pengaruh Pemberian Filtrat Bawang Merah dengan Berbagai Konsentrasi dan Rootone-F terhadap Pertumbuhan Stek Batang Tanaman Jambu Biji (Psidium guajava L).LenteraBio Vol. 1 No. 2 Mei 2012: 99-103. Jurusan Biologi, Fakultas Matematika dan Ilmu Pengetahuan Alam. Universitas Negeri Surabaya.

Pasetriani ET. 2013.Pengaruh Macam Media Tanam Dan Zat Pengatur Tumbuh Growtone Terhadap Pertumbuhan stek Batang Tanaman Jarak Pagar (Jatropa Curcas Linn). Karya Ilmiah. Smk Padalarang.

Prakasa. K.E, 2011.Pengaruh Pemberian Zpt (Rootone-F)
Terhadap Pertumbuhan Stek Duabanga Moluccana, Blume. Skripsi. Fakultas Kehutanan Institut Pertanian Bogor.

Sulistiana Susi. 2013. Respon Pertumbuhan Stek Daun Lidah Mertua (Sansevieria Parva) Pada Pemberian Zat Pengatur Tumbuh Sintetik (Rootone-F) Dan Asal Bahan Stek.Jurnal Matematika, Sains, dan Teknologi, Volume 14 Nomor 2. September 2013; 107-118 .Jurusan Biologi FMIPA, Universitas Terbuka.

Syakhril dan Rismawati. 2012. Respons Asal Bahan Stek Sirih Merah (Piper Crocatum Ruiz And Pav.) Terhadap Konsentrasi Rootone F. Prodi Agroteknologi Pertanian Fakultas Pertanian Universitas Mulawarman. 